\title{
Construction and Validation of the Character Strengths Scale for Youth (CSS-Youth)
}

\author{
Denise Martins Dametto ${ }^{1}$ (D) https://orcid.org/0000-0002-2880-5113 \\ Ana Paula Porto Noronha ${ }^{1}$ (D) https://orcid.org/0000-0001-6821-0299
}

\begin{abstract}
Character strengths are positive individual characteristics that may be expressed through thoughts, feelings and actions. The present study aimed to build an instrument to assess the virtues and character strengths of adolescents and to seek psychometric evidence for the scale. A total of 836 adolescents participated, between the ages of 14 and 18 and enrolled in high school, being $60.4 \%$ girls. Students responded to the Character Strengths Scale for Youth (CSS-Youth). Judges' analysis indicated that CSS-Youth has evidence of content validity. Confirmatory factorial analysis allowed the extraction of five factors, and the alpha coefficient showed good accuracy. The initial psychometric data for CSS-Youth is promising, but further studies are necessary to find other validity evidence, as well as new analyses to test the factorial structure of the model used.
\end{abstract}

Keywords: psychological assessment, positive psychology, test construction

\section{Construção e Validação da Escala de Forças de Caráter para Adolescentes (EFC-A)}

\begin{abstract}
Resumo: Forças de caráter são características individuais positivas que podem ser expressas por meio de pensamentos, sentimentos e ações. Os objetivos deste estudo foram construir um instrumento para avaliar as virtudes e forças de caráter de adolescentes e buscar evidências psicométricas para a escala. Participaram 836 adolescentes entre 14 a 18 anos, estudantes do Ensino Médio de escolas públicas, sendo 60,4\% meninas. Os alunos responderam a Escala de Forças de Caráter para Adolescentes (EFC-A). A análise de juízes indicou que a EFC-A possui evidências de validade de conteúdo. A análise fatorial confirmatória permitiu a extração de cinco fatores, bem como o coeficiente alfa mostrou boa precisão. Os dados psicométricos iniciais para a EFC-A são promissores, porém são necessários novos estudos para buscar outras evidências de validade, bem como novas análises para testar a estrutura fatorial do modelo utilizado.
\end{abstract}

Palavras-chave: avaliação psicológica, psicologia positiva, construção de teste

\section{Elaboración y Validez de la Escala de Fuerzas de Carácter para Adolescentes (EFC-A)}

\begin{abstract}
Resumen: Las fuerzas de carácter son características individuales positivas que pueden expresarse por medio de pensamientos, sentimientos y acciones. El presente estudio tuvo como objetivo elaborar un instrumento para evaluar las virtudes y fuerzas de los adolescentes, y buscar evidencias psicométricas para la escala. Participaron 836 adolescentes de entre 14 y 18 años de edad, estudiantes de la enseñanza media, siendo el 60,4\% niñas. Los estudiantes respondieron a la Escala de Fuerzas de Carácter para Adolescentes (EFC-A). El análisis de los evaluadores apunta evidencia de validez de contenido en la EFC-A. El análisis factorial confirmatorio permitió extraer cinco factores, y el coeficiente alfa se mostró de buena precisión. Los datos psicométricos iniciales para la EFC-A son prometedores, aunque se necesita más estudios para encontrar otras evidencias de validez, así como nuevos análisis para probar la estructura factorial del modelo utilizado.
\end{abstract}

Palabras clave: evaluación psicológica, psicología positiva, construcción de pruebas

${ }^{1}$ Universidade São Francisco, Campinas-SP, Brazil

Article derived from the doctoral thesis of the first author under the supervision of the second, defended in 2017, in the Stricto Sensu Postgraduate Program in Psychology of the Universidade São Francisco. Support: CAPES. Support: 1.245.129

Correspondence address: Denise Martins Dametto. Universidade São Francisco. Psicologia. Rua Waldemar César da Silveira, Campinas-SP, Brazil. CEP. 13.045-510. E-mail: denisedametto@gmail.com
Virtues and character strengths can be characterized as an area of research within Positive Psychology that focuses on the positive qualities of the human being. Cawley, Martin and Johnson (2000) define virtue as the quality that each individual possesses, being valued as a basis of principles and moral well-being. In relation to the construct character strengths, Peterson and Seligman (2004), describe them as 
individual characteristics that can be manifested through thoughts, feelings and actions. These are understood by Peterson and Seligman (2004) as psychological "ingredients" that together make up the virtues, which are distinct routes that can be used to complement them.

The development study of strengths and virtues in adolescents has attracted the attention of researchers, since they can contribute to good results such as school success, leadership, tolerance, kindness and altruism (Park, 2009). Based on empirical evidence, Peterson and Seligman (2004) observed that adolescents who participated in school programs that were designed to cultivate character strengths were less likely to have problems such as school failure, drug use, alcohol abuse, smoking, violence, teenage pregnancy, depression and suicidal ideation.

Stimulating certain character strengths contributes not only to happier and healthier students, but it also helps them to achieve a more positive performance. Based on this approach, investigations on adolescent character strengths are necessary, since parents, educators, and professionals can help teens to use them in their lives, relationships, leisure, and in school (Park, 2009).

The study of the character strengths of adolescents contributes for positive thoughts, feelings and actions, even though when life's adversities is considered. Additionally, improving individuals' mental health during adolescence can have beneficial effects if they learn skills and behaviors that can be applied throughout the course of life. Also, highlighting positive emotions, valuing what brings pleasure, does not mean avoiding sadness or anguish, but being able to contribute to increase the capacity to reflect on the positive aspects of life in which negative emotions are found, thus serving as a coping mechanism (Norrish \& Vella-Brodrick, 2009).

In relation to strengths and virtues, Peterson and Seligman (2004) developed the Values in Action (VIA) Classification of Strengths, which consists of 24 character strengths, organized into six virtues, which are: Wisdom (creativity, curiosity, open-mindedness, love of learning and perspective), Courage (bravery, persistence, integrity and zest), Humanity (love, kindness and social intelligence), Justice (teamwork, fairness and leadership), Temperance (forgiveness, modesty, prudence and self-regulation) and Transcendence (appreciation of beauty, gratitude, hope, humor and spirituality). In order for the concepts to be evaluated, Peterson and Seligman (2004) created the Inventory of Strengths (VIA-IS), which is a selfreport questionnaire for adults over 18 years old. For children and young people aged 10 to 17 , the authors developed the Inventory of Strengths for Youth (VIA-Youth).

Research related to the VIA-Youth have been conducted in several countries in order to demonstrate the credibility of the scale in the identification and evaluation of the character strengths of adolescents (Grinhauz \& Castro Solano, 2013; Park \& Peterson, 2006; Ruch, Weber, Park, And Peterson, 2014; Toner, Haslam, Robinson, \& Williams, 2012; Van Eeden, Wissing, Dreyer, Park, \& Peterson, 2008). Table 1 shows international studies that translated and/or adapted VIA-Youth in their country of origin, and the results of these surveys indicated four to six factors for the scales.

Table 1

Summary of International Studies Related to the VIA-Youth

\begin{tabular}{llll}
\hline & Park and Peterson (2006) & Toner et al. (2012) & Ruch et al. (2014) \\
\hline Country & United States & Australia & Germany \\
$\mathrm{N}$ & 1,300 & 501 & 1,569 \\
Age & 10 to 17 years & 15 to 18 years & 10 to 17 years \\
Factor 1 & $\begin{array}{l}\text { Temperance: prudence, self- } \\
\text { regulation, persistence and } \\
\text { integrity }\end{array}$ & $\begin{array}{l}\text { Temperance: prudence, } \\
\text { persistence, self-regulation, humor, perspective, social } \\
\text { integrity, open-mindedness } \\
\text { and hope }\end{array}$ & $\begin{array}{l}\text { intelligence and bravery } \\
\end{array}$
\end{tabular}

Factor 2 Intellectual Qualities: love of learning, creativity, curiosity, appreciation of beauty, fairness and open- mindedness

Factor 3 Theological Strengths: hope, spirituality, love, zest, gratitude, social intelligence, perspective, humor, leadership and forgiveness

Factor 4 Interpersonal Strengths: modesty, kindness, teamwork and bravery

Factor 5
Zest: humor, leadership, bravery, perspective, zest and social intelligence

Curiosity: curiosity, love of learning, creativity and appreciation of beauty

Interpersonal Strengths: modesty, kindness, forgiveness, fairness and teamwork

Transcendence: spirituality, Transcendence: modesty, love and gratitude
Temperance: prudence, self-regulation, persistence and integrity

Intellectual Strengths: curiosity, love of learning, appreciation of beauty and creativity

Interpersonal Strengths: spirituality, zest, gratitude, love and hope

forgiveness, kindness, fairness and teamwork

Grinhauz and Castro Solano (2013)

Argentina

518

10 to 12 years

Temperance Strengths: persistence, self-regulation, open- mindedness, integrity, prudence, and modesty

Empathy Strengths: appreciation of beauty, love, gratitude, kindness, humor and perspective

Knowledge Strengths: creativity and love of learning

Social strengths: social intelligence, spirituality and bravery

Justice Strengths: fairness, teamwork and leadership

Justice, curiosity, hope and zest 
The results of Grinhauz and Castro Solano (2013), Park and Peterson (2006), Ruch et al. (2014) and Toner et al. (2012) studies partially agree. Although Toner et al. and Ruch et al. have identified five factors, the authors of the four research made similar groupings, namely, Temperance, Interpersonal/Social Strengths/Empathy, Qualities or Intellectual and Knowledge Strengths, and Curiosity, which was indicated in the study by Toner et al. and considered by the authors as an intellectual strength, since it belongs to the Wisdom virtue. Another similarity was the grouping of the Theological Strengths, or Transcendence. However, Toner et al. (2012) named it the Zest factor and Ruch et al. (2014) the Leadership factor.

In Brazil, Seibel, DeSouza and Koller (2015) translated and adapted the VIA-IS instrument for the Brazilian population. The sample for the study was 1.975 individuals from 18 to 82 years old. The strength scores were submitted to exploratory factorial analyses to investigate the factorial structure of virtues of the Brazilian version of the questionnaire. Preliminary analyses showed the adequacy of the sample for the Exploratory Factor Analyses (KMO $=0.95$ and Bartlett index $=35784.3 ; \mathrm{gl}=276, p<0.001$ ). The Hull method suggested the extraction of a single factor, while the parallel analysis method suggested the extraction of three or four factors. Both the single-factor solution and the multifactorial solutions agreed with data from other studies. This suggests different interpretations of each factor extracted depending on the culture in which the VIA-IS instrument was applied. However, it is worth mentioning that, through the Hull method, the unifactoral solution was indicated as the best result, because the factors were correlated (MacDonald, Bore, \& Munro, 2008; Van Eeden et al., 2008).

Noronha and Barbosa (2016) developed the Character Strengths Scale (CSS), based on the VIA. The authors opted for the creation of a new instrument due to the particularities of the Brazilian population, as well as issues related to copyright. Subsequently, in the study of Noronha, Dellazzana-Zanon and Zanon (2015), the authors aimed to evaluate the internal structure of the CSS, with the participation of 426 university students, aged between 18 and 57 years. Through the Maximum Likelihood, a parallel factor analysis of extraction method, the authors found a one-dimensional solution, with an alpha coefficient of 0.93 .

Despite the contribution of these studies to Positive Psychology, there is still no instrument to evaluate character strengths and virtues in adolescents in Brazil, which reaffirms the importance of this study. Regarding the VIA, it should be noted that, in the studies that sought to replicate the model, none of them found the six virtues proposed by Peterson and Seligman (2004). Despite the agreement between the investigations by Park and Peterson (2006), Ruch et al. (2014) and Toner et al. (2012), the studies by Noronha et al. (2015), Seibel et al. (2015), as well as Van Eeden et al. (2008) should also be considered. The latter authors used the South African version of the VIA-Youth in 1.691 adolescents aged 13 to 17 years and, through factorial and confirmatory analysis, found only one factor, with an alpha coefficient of .93 affirming the unidimensionality of the instrument.

Poseck (2006) considers pioneering the initiative of Peterson and Seligman (2004) to develop an instrument based on Positive Psychology. Although, the Positive Psychology movement has produced recently important applications and scientific advances, developing studies with several constructs, such as resilience, happiness, life satisfaction, subjective well-being, hope, self-efficacy, self-esteem, optimism and affection, indicating a growth of this field (Hutz, 2014). This study aimed to build an instrument to evaluate the virtues and character strengths of adolescents and to seek psychometric evidence for the scale. The specific objectives were: (1) to seek evidence of content validity, through judges' analysis, (2) conduct a pilot study, (3) investigate the internal structure of the scale, and (4) estimate the accuracy of the instrument.

\section{Method}

\section{Construction of the instrument}

Firstly, for the elaboration of the instrument, a theoretical review was made, mainly using the Peterson and Seligman (2004) classification model. To facilitate the creation and organization of items, each virtue and its definition were set forth in a spreadsheet, as well as the 24 character strengths pertaining to each of the six virtues and their respective descriptions. Also, the items of the CSS instrument (Noronha \& Barbosa, 2016) and the VIAYouth items, each one identified according to the strength belonging to it, were inserted in the spreadsheet. The two instruments were used as auxiliaries in the elaboration of the new items, especially the VIA-Youth, to be possible to create items directed to adolescents.

Next, the items were built considering the criteria pointed out by Pasquali (2010), which are objectivity, simplicity, clarity, relevance, precision, variety, modality, typicality, credibility and breadth. The operationalization of the items occurred from the constitutive definition of each of the 24 character strengths. Thus, the first author of this study elaborated five items for each of the 24 strengths, organized in the six virtues. Then the items were reviewed by the second author of this study regarding content adequacy, used words and semantic analysis.

\section{Participants}

In view of the proposed objective, the study had different samples for each of the steps performed. For the judges' analysis, the items constructed were considered by $13^{*}$ judges, chosen by convenience, who were doctors in Psychology with experience in the field of Positive Psychology. For the pilot study, $23^{*}$ Elementary and High School students between the ages of 13 and 18 collaborated, of which $87 \%$ were females and $91.3 \%$ attended public 
schools. Finally, in the last step, $836^{*}$ Brazilian high school students from public schools participated, aged 14 to 18 years old $(M=15.47 ; S D=1.079)$, of which $60.4 \%$ were female.

\section{Instruments}

The material sent to the judges via e-mail consisted of a file with four pages. Each of these pages was formed by the items of six random strengths. Among these items, distracting items of two strengths were placed, and the judges should identify those who were not part of the indicated group of strengths. For example, integrity, selfregulation, bravery, persistence, prudence and zest were shown in the first page. Distracting items were part of the strengths modesty and hope. In this way, the experts should point out the 10 items of modesty and hope, since they were not part of the group offered. For the second stage of the judges' analysis, the material sent to the specialists was organized with a column with the sequenced items, a column with the name of the strength to which the item belonged and two other columns with yes and no, so that the judge could indicate if an item was in accordance with the strength assigned to it.

Regarding the pilot study, the adolescents received an initial version of the Character Strengths Scale for Youth (CSS-Youth), with a header to be completed by name, age, e-mail, sex, city/state, school (public or particular), period and school year ( $1^{\text {st }}$ year, $2^{\text {nd }}$ year and $3^{\text {rd }}$ year). The instructions given were: "Below you will find a list of sentences that describes thoughts, feelings, and behaviors. Please read each statement and decide how each one sounds like you and mark an $\mathrm{X}$ in your answer. Choose from 1 to 4 , from nothing like me (1) to completely like me (4). There are no right or wrong answers. Be as honest as possible." All 120 items were randomly shown in a single column, and the questionnaire was administered to 23 adolescents.

The scale was then applied to 220 adolescents from a public school. It is worth mentioning that, after this stage, there was a reorganization suggested by the judges, and 48 items (two items from each strength) were changed to the negative direction, in order to control acquiescence, since the developed scale is composed of positive items which can be easily endorsed, contributing to a considerable social desirability. Thus, the protocols of 616 students had the items reversed during the analyses. Data can be checked in the Results section.

\section{Procedure}

Data collection. In order for the judges' analysis to take place, an invitation letter was sent via electronic mail requesting the collaboration of 10 specialists, along with the items, with the instruction to identify the item that did not belong to the strength group. From this material, the analyses were performed. After the changes made, following the suggestions of the experts, we proceeded to a second moment. Again, an invitation letter requesting the collaboration of three judges was sent via e-mail. They were asked to indicate with an $\mathrm{X}$ the yes or no alternative, which referred to whether the item was in accordance with the strength rating indicated in the next column.

Subsequently, some items were reformulated, resulting in another version for data collection. In this way, the pilot study was carried out with the participation of 23 adolescents who were part of a social network of the first author of this study, being applied individually. They were asked to read the instructions as well as the sentences of all items. If there was any doubt as to the language used, they should circulate the word and note the doubt at the end of the page. The purpose of this procedure was to evaluate the clarity of the items, the semantic analysis and the instructions present in the scale. After this procedure, the CSS-Youth was assessed on the students at the schools by three researchers of a graduate program, collectively, in the classroom, in a single session, with an approximate duration of 40 minutes.

Data analysis. In order to verify the experts' comments regarding the items in the judges' analysis, a qualitative analysis was used, considering the comments and suggestions of each judge. Then, an agreement of $70 \%$ (Landis \& Koch, 1977) was considered between the answers of the judges, using a score of 0 (when the judge marked the wrong one or did not mark the right one), 1 (when they did not marked the wrong one) and 2 (when they marked the correct one). For the CSS-Youth factorial validity evidence, we used the confirmatory factorial analysis (CFA), through the Maximum Likelihoood (ML) method of estimation, in the bifactor model. The models were tested from the indexes $\mathrm{c}^{2}$, gl, CFI, TLI and RMSEA. These analyses were performed using the statistical package Mplus 7. To verify the accuracy of the scale, the alpha coefficient was used.

\section{Ethical Considerations}

This study was submitted and approved by the Research Ethics Committee of the Universidade São Francisco (CAAE $\left.\mathrm{n}^{\circ} 48682915.6 .0000 .5514\right)$. The CSS-Youth was administered only to students who showed an Informed Consent Form signed by their parents. 18-year-old students signed their own form.

\section{Results}

In order to verify the consistency of the answers of the first stage of the judges' analysis, a qualitative analysis was carried out, considering the specialists' comments on the content of the items. The first moment occurred with the verification of the agreement between the classification done by the authors of this study and by the judges for each item within a group of six strengths, and there were distracting items of two strengths. The score given was 
from 0 to 2. For this, we considered an agreement of $70 \%$ (Landis \& Koch, 1977) among the specialists, and the items equal to or less than this value were reviewed.
Table 2 indicates the name of each strength, the number of the item, the original item and the percentage of agreement between the judges.

Table 2

Agreement between the Answers of the Judges'analysis (first stage)

\begin{tabular}{|c|c|c|c|}
\hline Strengths & Item & Original Item & Agreement \\
\hline Love & 32 & I like to be around people. & $30 \%$ \\
\hline Love & 40 & When I need to, I have someone to count on. & $40 \%$ \\
\hline Appreciation of beauty & 7 & I have great admiration for nature. & $70 \%$ \\
\hline Appreciation of beauty & 34 & Very intelligent people fascinate me. & $10 \%$ \\
\hline Appreciation of beauty & 42 & I appreciate the little things of my daily life. & $30 \%$ \\
\hline Appreciation of beauty & 51 & I really like going to the movies and/or theater. & $70 \%$ \\
\hline Appreciation of beauty & 107 & I am an admirer of classical music. & $70 \%$ \\
\hline Integrity & 8 & I would not lie to gain anything from anyone. & $30 \%$ \\
\hline Integrity & 68 & It is important for me to be open and honest about my feelings. & $10 \%$ \\
\hline Self-Regulation & 58 & I can control what I eat. & $0 \%$ \\
\hline Bravery & 26 & I do what needs to be done, despite being afraid. & $0 \%$ \\
\hline Curiosity & 71 & I ask questions frequently. & $10 \%$ \\
\hline Hope & 64 & I feel confident to achieve my goals. & $20 \%$ \\
\hline Hope & 108 & Despite the challenges, I have hope for the future. & $50 \%$ \\
\hline Hope & 114 & If I strive and have faith, everything will be different. & $50 \%$ \\
\hline Gratitude & 11 & I am grateful for the lives of the people around me. & $10 \%$ \\
\hline Social intelligence & 66 & I respect different ideas. & $30 \%$ \\
\hline Social intelligence & 88 & I can deal with my feelings. & $60 \%$ \\
\hline Leadership & 85 & When I work in a group, I like to be the presenter. & $60 \%$ \\
\hline Leadership & 100 & I can naturally create a pleasant environment during a group work. & $40 \%$ \\
\hline Modesty & 15 & I know my mistakes. & $70 \%$ \\
\hline Open-mindedness & 24 & I analyze all the points before making any decision. & $0 \%$ \\
\hline Open-mindedness & 57 & I consider myself an open-minded person. & $0 \%$ \\
\hline Open-mindedness & 111 & I know when I'm wrong. & $40 \%$ \\
\hline Zest & 55 & I have a lot of energy all day. & $80 \%$ \\
\hline
\end{tabular}

As shown in Table 2, the strength appreciation of beauty had all items reformulated, since the content of the items was not capturing the description of the strength. Likewise, the strengths hope and open-mindedness have undergone changes in most of their items. It is worth mentioning that an agreement of $0 \%$ was given to items that the judges scored as not belonging to the indicated strength.

It is necessary to point out that not all items received comments and/or suggestions from the experts. Some items only received indications that they did not agree with the indicated strength group. Thus, it was necessary to review them. Examples of the comments made were items 26 (perhaps relativize it a little, as it is, it's too strong), 32 (seems an item from the Extroversion factor), 68 (maybe it is better to decompose these two information into two items) and 114 ("having faith" is related to religious belief, remove that part from the item, as it may bias the answers).

Next, it was decided to carry out a further step in the judges' analysis in order to seek for evidence of content validity, considering a structure of "yes" or "no" answers for the classification of each item within each strength. This involved three judges. Table 3 shows the name of the strength, the item number, the item and the agreement of the judges' answers, and only the values below $70 \%$ were exposed. It should be noted that items 15, 40, 108 and 114 were modified after the first analysis.

Table 3 indicates that nine items had agreement of $66 \%$ between the judges' answers, and five items showed 
agreement of $33 \%$. The 14 items that did not have agreement were maintained after being reformulated according to the experts' suggestions (described in Table 3). A qualitative analysis followed the comments and suggestions for the format of some items. These are shown in Table 4, as well as their final version.

Table 3

Agreement between the Answers of the Judges'analysis (second stage) to Seek for Validity Evidence

\begin{tabular}{lcll}
\hline Strengths & Item number & Item & \\
\hline Love of learning & 105 & I like to study new things. \\
Kindness & 119 & I believe giving is more important than receiving. \\
Bravery & 94 & If necessary, I can face a fight. \\
Bravery & 95 & I do not give in to pressure from my friends to do something that I \\
Creativity & 93 & know is wrong. \\
Hope & 86 & My ideas are always different from other people. \\
Spirituality & 74 & I have faith that things will be better for me. \\
Gratitude & 27 & I value my beliefs. \\
Humor & 6 & I know good things happen in my life. \\
Fairness & 81 & I always look at the positive side of things. \\
Modesty & 33 & Everyone deserves respect. \\
Perspective & 16 & I always think of others before thinking of me. \\
Perspective & 43 & I consider the opinions of others to make my decisions. \\
Perspective & 97 & I often give my opinion to my friends when they ask me. & $66 \%$ \\
\hline
\end{tabular}

Table 4

Comments and Suggestions for Items in the Second Judge Analysis

\begin{tabular}{|c|c|c|}
\hline Item & Comments/Suggestions & Final version of the item \\
\hline 94 & The content of the item resembles the integrity strength. & $\begin{array}{l}\text { I do not usually retreat in the face of } \\
\text { difficulties. }\end{array}$ \\
\hline 93 & $\begin{array}{l}\text { Having different ideas may not necessarily be creativity. This can be seen as } \\
\text { something negative. }\end{array}$ & My ideas are always more creative. \\
\hline 86 & Mix of spirituality with religiosity. Faith is not part of the hope construct. & I believe things will be better for me. \\
\hline 74 & The word "beliefs" may not be only related to spiritual beliefs. & Spirituality is an important thing in my life. \\
\hline 27 & Being aware does not seem to mean being grateful. & I know good things happen in my life. \\
\hline 6 & $\begin{array}{l}\text { It is part of the definition of strength, but this is a facet of optimism and not } \\
\text { just humor. Should it really be within the humor strength? It could be hope, for } \\
\text { example. }\end{array}$ & I'm a playful person. \\
\hline 33 & $\begin{array}{l}\text { It seems to be closer to humility, kindness, giving, self-transcending, etc. It } \\
\text { does not seem to be modesty. }\end{array}$ & I know my limitations. \\
\hline 16 & $\begin{array}{l}\text { The definition talks about giving advice to other people. As it is, the item is in } \\
\text { decision-making. In addition, it could be confused with open-mindedness. }\end{array}$ & $\begin{array}{l}\text { I reflect before deciding the best way to } \\
\text { follow. }\end{array}$ \\
\hline 43 & $\begin{array}{l}\text { It does not seem to be perspective. The opinion may be quite foolish, for } \\
\text { example. }\end{array}$ & $\begin{array}{l}\text { I have good sense to know how to behave in } \\
\text { different situations. }\end{array}$ \\
\hline 97 & Perhaps "what to do" is more faithful to the definition of the strength. & $\begin{array}{l}\text { I often know what to say in difficult } \\
\text { situations. }\end{array}$ \\
\hline
\end{tabular}

From the comments made by the judges described in Table 4, it is noted that some items were describing the content of other related strengths. In addition, words that should be reviewed in the description of the items were indicated.
Regarding the pilot study, only two comments were made. The first was regarding the item 10 from the openmindedness strength (I think a lot and if it's worth it, I'm able to change my mind). It was indicated that the item 
was confusing. So it was changed to "I think a lot about a situation and, if it's worth it, I'm able to change my mind" so that the understanding becomes clearer. The second comment was for item 83 from the teamwork strength (it is important to take care of the environment). One teenager said:

The whole questionnaire revolves around how I would think or how I act and live, but in this item I wondered if it was in relation to what I think about myself or about society in general, whether it is important for me to take care of the environment or if I think it's important that everyone takes care of it.

That way, the item was reformulated to "it is important to do my part to take care of the environment". After the change, this version of the scale was assessed in 220 adolescents from a public school.
It is necessary to point out that, after the first assessment, 48 items (two items from each strength) were modified to the negative direction, which was a suggestion of the judges, in order to control acquiescence. For example, the item 62 of the perspective strength, which was originally "I believe I am able to give good advice", was changed to "I believe I am not able to give good advice." This version was answered by 616 adolescents. For the data analysis, these 48 items were again inverted.

In order to seek for factorial validity evidence for the CSS-Youth, the CFA was used, through the Maximum Likelihoood (ML) method, in the bifactor model. The results of the overall adjustment were $\mathrm{c}^{2} / \mathrm{gl}$ of $361.036 ; \mathrm{c}^{2} / \mathrm{gl}$ of .99 , $p .001 ; \mathrm{RMR}=.025 ; \mathrm{RMSEA}=.027 ; \mathrm{CFI}=.945 ; \mathrm{TLI}=.896$. As can be seen in Table 5, the five-factor cluster provided the best solution. Also, in the same table, the alpha coefficients are indicated for the 24 strengths of the scale, with the total scale having an alpha coefficient of .94. The results showed that the scale has good internal consistency.

Table 5

Alpha coefficients and Confirmatory Factorial Analysis of CSS-Youth $(N=836)$

\begin{tabular}{|c|c|c|c|c|c|c|c|}
\hline Strengths & alpha & $\begin{array}{l}\text { General } \\
\text { Factor }\end{array}$ & 1 & 2 & 3 & 4 & 5 \\
\hline Love & .51 & $.551^{*}$ & $-.26^{*}$ & .06 & .01 & -.10 & -.16 \\
\hline Love of learning & .59 & $.498^{*}$ & .06 & $-.25^{*}$ & -.03 & .19 & .14 \\
\hline Appreciation of beauty & .67 & $.557^{*}$ & $.38^{*}$ & -.00 & .03 & $-.44 *$ & -.02 \\
\hline Integrity & .42 & $.369 *$ & $-.44^{*}$ & .04 & .14 & .04 & -.07 \\
\hline Self-Regulation & .56 & $.636^{*}$ & $.31^{*}$ & $-.33^{*}$ & .06 & -.08 & .03 \\
\hline Kindness & .70 & $.533^{*}$ & .00 & $-.27 *$ & -.07 & .08 & -.19 \\
\hline Bravery & .42 & $.587 *$ & -.04 & -.10 & -.02 & $-.27^{*}$ & -.03 \\
\hline Teamwork & .62 & $.350 *$ & $-.54 *$ & -.02 & -.01 & -.01 & -.26 \\
\hline Creativity & .65 & $.593^{*}$ & $-.19 *$ & -.06 & .01 & .08 & -.14 \\
\hline Curiosity & .55 & $.679 *$ & -.02 & .12 & $.25^{*}$ & -.07 & -.12 \\
\hline Hope & .69 & $.581 *$ & -.08 & -.08 & $.38^{*}$ & .01 & .10 \\
\hline Spirituality & .80 & $.720 *$ & $.19^{*}$ & .00 & $.27^{*}$ & -.04 & -.00 \\
\hline Gratitude & .72 & $.604 *$ & .10 & -.02 & .11 & .04 & -.12 \\
\hline Humor & .57 & $.598^{*}$ & $.18^{*}$ & $-.17^{*}$ & -.06 & -.11 & .07 \\
\hline Fairness & .47 & $.685^{*}$ & -.11 & -.03 & -.11 & .05 & -.00 \\
\hline Social intelligence & .47 & $.631 *$ & -.05 & -.03 & -.16 & $.14^{*}$ & -.10 \\
\hline Leadership & .68 & $.593^{*}$ & -.02 & .00 & -.23 & -.04 & .34 \\
\hline Modesty & .39 & $.645^{*}$ & -.17 & $.30^{*}$ & -.23 & -.05 & .11 \\
\hline Open-mindeness & .49 & $.579 *$ & -.04 & .06 & .01 & .15 & $.52 *$ \\
\hline Forgiveness & .73 & $.590 *$ & .14 & $.45^{*}$ & -.00 & -.03 & .11 \\
\hline Persistence & .57 & $.591 *$ & .04 & $.49^{*}$ & .01 & .08 & .14 \\
\hline Prudence & .71 & $.550 *$ & .21 & $.51^{*}$ & -.01 & .09 & -.02 \\
\hline Perspective & .46 & $.392 *$ & $.60^{*}$ & .03 & .05 & $.41^{*}$ & -.01 \\
\hline Zest & .69 & $.289 *$ & $.92 *$ & .01 & -.24 & .01 & -.05 \\
\hline
\end{tabular}


Five factors were extracted through the CFA, being named as: Factor 1 - interpersonal strengths; factor 2 - temperance strengths; factor 3 - theological strengths; factor 4 - intellectual and leadership strengths. Factor 5 was constituted only by the open-mindedness strength. The strengths gratitude, fairness and leadership did not appear on any of the factors. However, in the general factor, the commonalities of these strengths were shared among the 24 character strengths, and, through the bifactor model, it can be seen that all strengths contribute to a general factor of the construct character strengths, and each of them also collaborate for a specific factor, due to its unique variance besides the general factor.

\section{Discussion}

The construction of the items was carried out aiming to describe the content of each character strength. For this, we followed the recommendations of Pasquali (2010) regarding the operationalization of constructs and construction of scales. Concerning the appreciation of beauty, which concerns one who perceives and appreciates beauty, excellence and/or performance of abilities in various domains of life, from nature to art, from mathematics to science to everyday experience (Peterson \& Seligman, 2004), the content of the items was not capturing the definition of the concept. It can be said that the items were little tangible, not taking into account the variety and breadth referred to by Pasquali (2010). An example of this were items 7 (I have great admiration for nature) and 107 (I am a fan of classical music). It is believed that, for this reason, the judges' answers were low, especially in items 34 and 42 (very intelligent people fascinate me, I appreciate the small things of my daily life). Thus, these items have been replaced by "I like to observe the nature" (7), "I appreciate the beauty of natural landscapes" (34), "I find the sunset inspiring" (42), "I like to go to art exhibitions" (51), "I feel good when I hear good music" (107).

The definition of the strength hope, which refers to the person who expects the best for the future and works to achieve it, believing that a good future is something that can be achieved (Peterson \& Seligman, 2004), was not well represented in the items, because, according to the judges, they were referring more to faith and religious belief, as in the case of items 108 (despite the challenges, I have hope for the future) and 114 (if I strive and have faith, everything will be different). In that way, they have been changed to "despite the challenges, I believe things will work", and "if I try hard, everything will be different".

Yet, with regard to the strength open-mindedness, which is defined as thinking about things and examining them from all sides, not jumping to conclusions, being able to change your mind, considering all aspects (Peterson \& Seligman, 2004), there were minor changes to fit the description of the concept. Thus, items 24, 57 and 111 have been changed to "I analyze several points before making any decisions",
"I consider myself a critical person", and "I look for information to confirm popular beliefs".

Two items that showed a $0 \%$ agreement were reconsidered, that is, "I can control what I eat", from selfregulation strength, and "I do what needs to be done, despite being afraid", from the bravery strength. In this way, they have been replaced by "I have control over my appetite", and "I do what needs to be done, despite being afraid sometimes". These items, as well as others with agreement below $70 \%$, were better described in order to meet the criteria proposed by Pasquali (2010).

The completion of the second stage in the judges' analysis was intended to seek content validity evidence. The results were satisfactory, since there was a $100 \%$ agreement between the judges' answers for 106 items of the 120 that make up the scale. The 14 items that did not have agreement were maintained after being reformulated according to the experts' suggestions, none of which was indicated to be eliminated. In this way, it is endorsed that the scale has evidence of content validity (Pacico \& Hutz, 2015; Sireci, 1998), and the items consistently represented the data of the theory. However, although content validity is fundamental in the process of developing measurement instruments, it shows limitations because it is a subjective process, which its use does not eliminate the need to use other psychometric measures (Sireci, 1998). Thus, we opted for an empirical investigation through confirmatory factor analysis, as well as the analysis of the internal structure of the CSS-Youth.

The CFA allowed the extraction of five factors, not replicating the original classification of the character strengths organized into six virtues proposed by Peterson and Seligman (2004), which was also not found by other authors. In this study, factor 1 was named Interpersonal Strengths, composed by the strengths love, integrity, teamwork, creativity, humor, perspective and zest. The findings agree with Grinhauz and Castro Solano (2013), Park and Peterson (2006), Ruch et al. (2014) and Toner et al. (2012) studies, who also found similar groupings of strengths.

According to McGrath and Walker (2016), the strengths love, teamwork, humor and perspective are more related to the Humanity virtue proposed by Peterson and Seligman (2004), which explains why they are in this first factor, since they have interpersonal, as a social engagement. The integrity strength was present in the same factor only in Neto, Neto and Furnham (2014) study. In the sample of this research, this strength had a negative result, which may be related to the fact that these adolescents are not so genuine and honest, which can impact their social relations. Zest, which is more common in young people (Park \& Peterson, 2006; Toner et al., 2012), was also present in this factor in Neto et al. (2014) study, which may be related to the fact that the more energy the individual possesses, the more they will have social interactions. Regarding creativity, in the Grinhauz and Castro Solano (2013), Park and Peterson (2006) and Ruch et al. (2014) studies, this strength was more related to the intellect. It is worth noting that the creativity 
score was negatively related to interpersonal strengths. It is not clear why this strength shown in this factor, which needs to be better investigated in future studies.

Factor 2 was named Temperance Strengths, composed of the strengths love of learning, self-regulation, kindness, modesty, forgiveness, persistence and prudence, which is in line with the data from the Grinhauz and Castro Solano (2013), Neto et al. (2014), Park and Peterson (2006), Ruch et al. (2014) and Toner et al. (2012) studies. In relation to love of learning, in none of the studies it was present in the temperance group. It is believed that the young people in the sample have little interest in seeking new knowledge, since the score was negative. However, further investigations must be carried out in order to better understand why the strength was present in the temperance strengths factor.

Factor 3 was called Theological Strength, formed by curiosity, hope and spirituality. The authors Park and Peterson (2006), Ruch et al. (2014) and Toner et al. (2012), found similar groups, however, the strength curiosity was not present in this factor. It is possible that the adolescents in the sample have an interest in their own experience, and seek to find fascinating subjects and themes related to the meaning of the universe, or a connection to a higher being, with the intention of exploring and discovering more about it (Peterson \& Seligman, 2004).

Factor 4 grouped the Intellectual and Leadership Strengths, namely, appreciation of beauty, bravery and social intelligence, corroborating Neto et al. (2014), Park and Peterson (2006) and Ruch et al. (2014) results. Finally, factor 5 was formed only by the strength open-mindedness, which was not seen in other studies. This strength, in the original classification of Peterson and Seligman (2004), is part of the Wisdom virtue, but also was inserted in other groups like temperance(Grinhauz\& CastroSolano,2013, Ruchetal.,2014; Toner et al., 2012) and self-control (McGrath \& Walker, 2016). Although open-mindedness develops with age, maturing during childhood and in early adulthood (Park \& Peterson, 2006), it is unclear why this factor is composed of only one strength. Therefore, further investigations must be carried out to confirm this.

Gratitude, fairness and leadership have not shown in any of the factors, which may be related to the fact that they are more common in adults, which seems to reflect the influence of cognitive and social maturation and the different developmental needs throughout life. Or, the reason for this may have been the young age of most participants and their lack of opportunities to display these strengths (MacDonald et al., 2008; Park \& Peterson, 2006).

McGrath and Walker (2016) suggest that in adolescence, demonstration of loving feelings or leadership ability is more a consequence of zest or emotional engagement. With adulthood, as the level of maturity approaches, a more cognitive understanding emerges, based on strengths such as gratitude. Subsequent research is necessary for an understanding of how these strengths occur between adolescence and adulthood.
The initial psychometric data shown here are promising, especially with regard to the reliability of the Character Strengths Scale for Youth, since this indicated a good accuracy and promising validity. Additionally, this scale may be a useful tool to assist in assessing the adolescents' character strengths, both within the scientific context and for professionals working in schools. However, further work is needed to seek evidence of validity for the instrument.

It must be considered that the correlations found among many strengths demonstrate that each strength is not distinct, which contradicts the claims made by the creators of the VIA (MacDonald et al., 2008). The failure of any study of the VIA structure to generate results that approximate the original classification of six virtues should raise concerns about its use, at least as a classification to measure strengths. The focus on conceptually complex strengths resulted in the development of multidimensional scales, which made it difficult to identify an optimal latent model for the instrument (McGrath \& Walker, 2016). The discrepancy between the empirical evidence of the studies shown here may be related to the fact that the classification by Peterson and Seligman (2004) is based on theoretical foundations and can often not be replicated in practice (MacDonald et al., 2008).

This study has limitations that must be recognized, as they point the way for future research. First, the sample did not have a representative gender balance (it was mainly girls), as well as it did not encompass diverse cities and states in Brazil, and also did not evaluate students from private schools. Secondly, the measure used in this study was based exclusively on self-report questionnaires, and the acquiescence bias may have influenced some responses (Noftle, Schnitker, \& Robins, 2011). In this way, other studies can try to control this variable. In addition, it is important that the relationships between character strengths and other psychological constructs continue to be investigated, such as well-being and personality, in order to provide validation for the CSS-Youth. Finally, other possibilities of analysis should be conducted in order to test the factorial structure of the VIA.

\section{References}

Cawley, M. J. III, Martin, J. E., \& Johnson, J. A. (2000). A virtues approach to personality. Personality and Individual Differences, 28(5), 997-1013. doi:10.1016/ S0191-8869(99)00207-X

Grinhauz, A. S., \& Castro Solano, A. (2013). Validez factorial del Inventario de Virtudes y Fortalezas para Niños (IVYF Niños) [Factorial validity of the Children's Strengths and Virtues Questionnaire (IVYF Children)]. Anuario de Investigaciones, 20(1), 357-364. Retrieved from http://www.scielo.org.ar/scielo.php?script=sci arttext\&pid=S1851-16862013000100037 
Hutz, C. S. (2014). Avaliação em psicologia positiva [Assessment in positive psychology]. Porto Alegre, RS: Artmed.

Landis, J. R., \& Koch, G. G. (1977). The measurement of observer agreement for categorical data. Biometrics, 33(1), 159-174. doi:10.2307/2529310

MacDonald,C., Bore, M., \& Munro, D. (2008). Values in action scale and the Big 5: An empirical indication of structure. Journal of Research in Personality, 42(4), 787-799. doi:10.1016/j.jrp.2007.10.003

McGrath, R. E., \& Walker, D. I. (2016). Factor structure of character strengths in youth: Consistency across ages and measures. Journal of Moral Education, 45(4), 400-418. doi:10.1080/03057240.2016.1213709

Neto, J., Neto, F., \& Furnham, A. (2014). Gender and psychological correlates of self-rated strengths among youth. Social Indicators Research, 118(1), 315-327. doi: 10.1007/s11205-013-0417-5

Noftle, E. E., Schnitker, S. A., \& Robins, R. W. (2011). Character and personality: Connections between positive psychology and personality psychology. In K. M. Sheldon, T. B. Kashdan, \& M. F. Steger (Eds.), Designing positive psychology: Taking stock and moving forward (pp. 207-227). New York, NY: Oxford University Press. doi:10.1093/acprof:oso/9780195373585.003.0014

Noronha, A. P. P., \& Barbosa, A. J. G. (2016). Forças e virtudes: Escala de Forças de Caráter. [Strengths and virtues: Character Strengths Scale]. In C. S. Hutz (Org.), Avaliação em psicologia positiva: Técnicas e medidas [Assessment in positive psychology: Techniques and measures] (pp. 21-43). São Paulo, SP: Centro Editor de Testes e Pesquisa em Psicologia.

Noronha, A. P. P., Dellazzana-Zanon, L. L., \& Zanon, C. (2015). Internal structure of the Characters Strengths Scale in Brazil. Psico-USF, 20(2), 229-235. doi:10.1590/141382712015200204

Norrish, J. M., \& Vella-Brodrick, D. A. (2009). Positive psychology and adolescents: Where are we now? Where to from here? Australian Psychologist, 44(4), 270-278. doi:10.1080/00050060902914103

Pacico, J. C., \& Hutz, C. S. (2015). Validade [Validity]. In C. S. Hutz, D. R. Bandeira, \& C. M. Trentini (Orgs.), Psicometria [Psychometry] (pp. 71-84). Porto Alegre, RS: Artmed.

Park, N. (2009). Building strengths of character: Keys to positive youth development. Reclaiming Children and Youth, 18(2), 42-47. Retrieved from https://www. academia.edu/15498746/Building_Strengths_of_ Character_Keys_to_Positive_Youth_Development

Park, N., \& Peterson, C. (2006). Moral competence and character strengths among adolescents: The development and validation of the Values inAction Inventory of Strengths for Youth. Journal of Adolescence, 29(6), 891-909. doi:10.1016/j.adolescence.2006.04.011

Pasquali, L. (2010). Instrumentação psicológica: Fundamentos e práticas [Psychological instrumentation: Fundamentals and practices]. Porto Alegre, RS: Artmed.
Peterson, C., \& Seligman, M. E. P. (2004). Character strengths and virtues: A handbook and classification. Washington, DC: American Psychological Association.

Poseck, B. V. (2006). Psicología positiva: Una nueva forma de entender la psicología [Positive psychology: A new way of understanding psychology]. Papeles del Psicólogo, 27(1), 3-8. Retrieved from http://centrocppa.org/wp-content/ uploads/2015/11/PP-VERA-POSECK.pdf

Ruch, W., Weber, M., Park, N., \& Peterson, C. (2014). Character strengths in children and adolescents: Reliability and initial validity of the German Values in Action Inventory of Strengths for Youth (German VIAYouth). European Journal of Psychological Assessment, 30(1), 57-64. doi:10.1027/1015-5759/a000169

Seibel, B. L., DeSousa, D., \& Koller, S. H. (2015). Adaptação brasileira e estrutura fatorial da Escala 240-item VIA Inventory of Strengths [Brazilian adaptation and factor structure of the 240-item VIA Inventory of Strengths Scale]. Psico-USF, 20(3), 371-383. doi:10.1590/1413-82712015200301

Sireci, S. G. (1998). The construct of content validity. Social Indicators Research, 45(1-3), 83-117. doi:10.1023/A:1006985528729

Toner, E., Haslam, N., Robinson, J., \& Williams, P. (2012). Character strengths and wellbeing in adolescence: Structure and correlates of the Values in Action Inventory of Strengths for Children. Personality and Individual Differences, 52(5), 637-642. doi:10.1016/j.paid.2011.12.014

Van Eeden, C., Wissing, M. P., Dreyer, J., Park, N., \& Peterson, C. (2008). Validation of the Values in Action Inventory of Strengths for Youth (VIA-Youth) among South African learners. Journal of Psychology in Africa, 18(1), 143-154. doi:10.1080/14330237.2008.10820181

Denise Martins Dametto completed her postdoctoral training at The University of British Columbia, Kelowna-BC, Canada.

Ana Paula Porto Noronha is a Professor of the Universidade São Francisco, Campinas-SP, Brazil.

\section{Authors' Contribution:}

All authors made substantial contributions to the conception and design of this study, to data analysis and interpretation, and to the manuscript revision and approval of the final version. All the authors assume public responsibility for content of the manuscript.

Received: Mar. 22, 2017

1st Revision: Apr. 03, 2018

Approved: Jun. 13, 2018

How to cite this article:

Dametto, D. M., \& Noronha, A. P. P. (2019). Construction and validation of the character strengths scale for youth. Paidéia (Ribeirão Preto), 29, e2930 doi:http://dx.doi.org/10.1590/1982-4327e2930 